\title{
IV. IIvtizent.
}

\section{Wannung vor dem Eintritt in die pribatforjtoerwaltungs=}

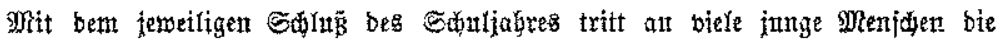

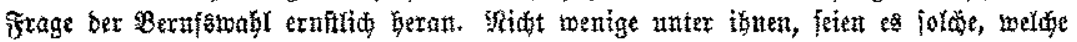

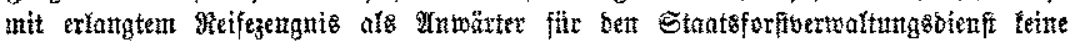
Wintabme gefunben baben, feien es folde, welde mit bem Einjübrigen=ßeugnts ans ber Edule ins \&eben treten, Goffen im Fribat= ober Bemetnbe=Forftberwaltungebienft eine

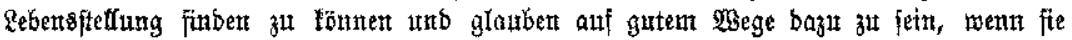

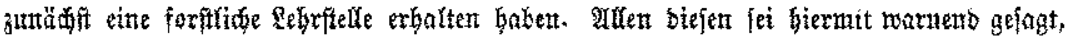

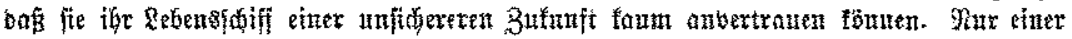

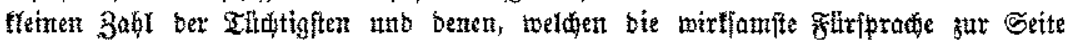

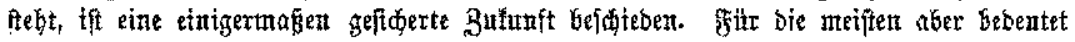

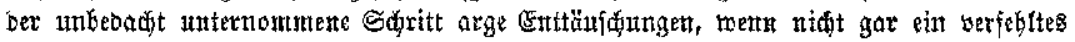

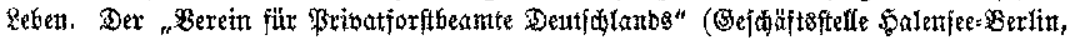

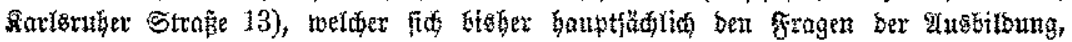

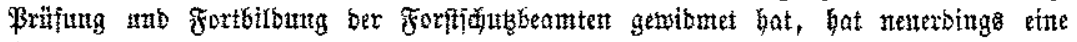
Kommifüan gebildet, waldie fid mit ber Iage - ober befier gefagt gotlage - ber

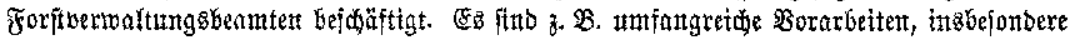

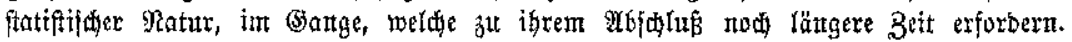

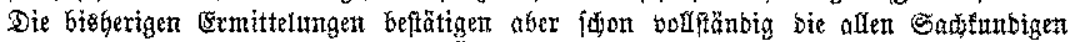

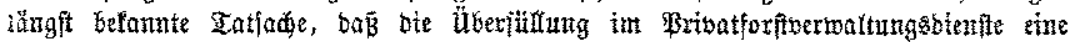

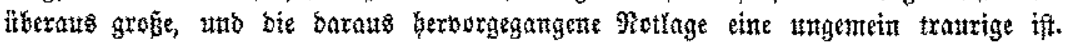

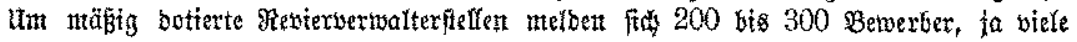

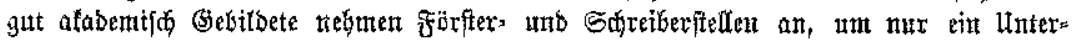

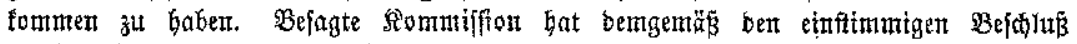

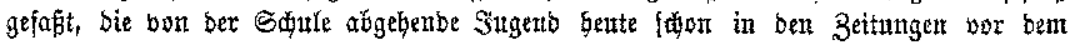

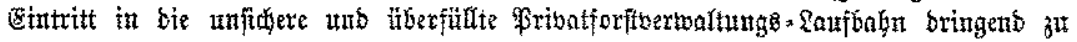

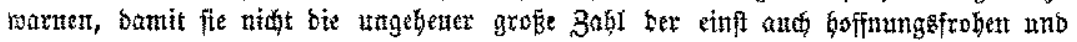

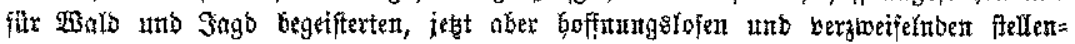

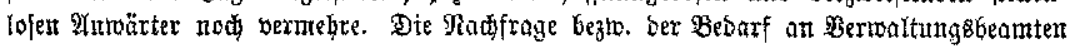

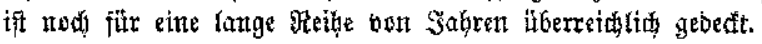

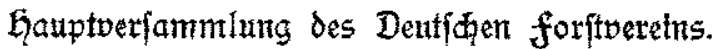

Die biesjäbrige b̆auptberfanmlung bes Deutfđen Ferftbereins finbet in ber 3 eit

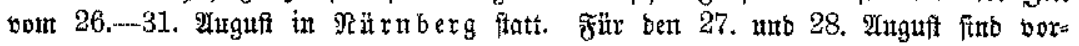

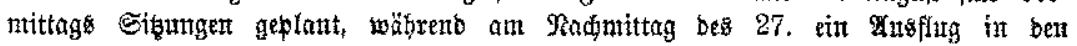

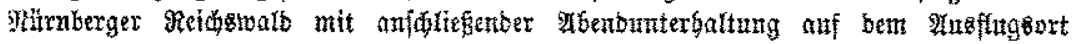
Sợmanfertbut burgefeben ift.

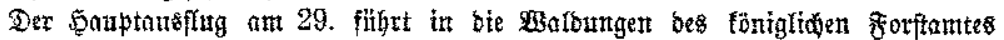

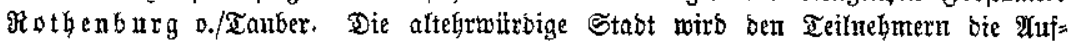
Führung bes biftortigen Feftipieles "Der Meiftertrunf“ Gieter.

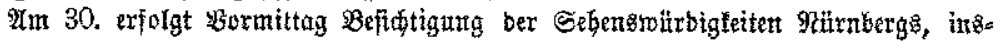

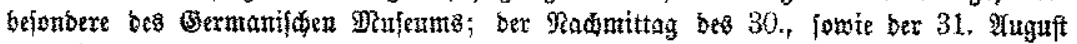

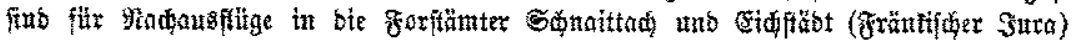

